\title{
Biological Activities and Characterization of Silver Nanoparticles from Prunus Prescia (L.) Batsch
}

\author{
Syeda Hajira Naqvi ${ }^{1(\mathbb{D})}$, Taiba Naseem ${ }^{2, *(\mathbb{D})}$, Ajmal Aziz ${ }^{1(\mathbb{D})}$, Gulam Mujtaba Shah ${ }^{3(\mathbb{C})}$ \\ Department of Chemistry, the University of Azad Jammu and Kashmir, Muzaffarabad-13100, Pakistan \\ Department of Chemistry, COMSATS University Islamabad, Islamabad-46000, Pakistan \\ Department of Botany, Hazara University Mansehra, Pakistan \\ Correspondence: taiba_durrani@yahoo.com;
}

Scopus Author 57216799692

Received: 27.11.2020; Revised: 4.01.2021; Accepted: 12.01.2021; Published: 19.01.2021

\begin{abstract}
In this paper, Prunus persica L. Batsch (wild and variety) plants have been used for the bioreduction of silver ions to silver nanoparticles. Aqueous leaf extract of plants was treated with silver nitrate. The mixture's color changed from pale yellow to dark brown Prunus persica (variety) and dark yellow to greyish brown Prunus persica (wild). The color change was the first indication of silver nanoparticle synthesis, further confirmed by UV-Vis spectroscopy. The surface Plasmon band exhibited absorption peaks for Prunus persica wild and variety leaf extract at $468 \mathrm{~nm}, 492 \mathrm{~nm}, 462 \mathrm{~nm}$. The silver nanoparticles were further characterized using X-Ray Diffraction that carried out the crystallographic nature by exhibiting $2 \theta$ value from $10^{\circ}$ to $90^{\circ}$ corresponding diffraction planes of Face Centered Cubic structure. Fourier Transform Infrared spectroscopy demonstrated organic compounds in plant material that mainly involved in reduction. Prunus persica L. Batsch (wild and variety) mediated silver nanoparticles exhibited excellent antibacterial activity against a human bacterial pathogen. The antioxidant activity was also studied that showed effective results on synthesized silver nanoparticles using the 1,1-Diphenyl-2-picrylhydrazyl (DPPH) radical scavenging assay. The result showed that Prunus persica L. Batsch proved to be a useful silver nanoparticle.
\end{abstract}

Keywords: silver oxide nanoparticles; anti-microbial activity.

(C) 2020 by the authors. This article is an open-access article distributed under the terms and conditions of the Creative Commons Attribution (CC BY) license (https://creativecommons.org/licenses/by/4.0/).

\section{Introduction}

Today, nanoscience has led rapidly to the development of a wide variety of different synthesised metal nanoparticles (MNPs). Due to the unique physicochemical properties of MNPs and their shapes, a promising scientific area of research has emerged for biotech applications in environmental bioremediation, biomedicine, drug delivery, optical and electronic, and bioimaging applications [1]. For example, MNPs have increased electrical conductivity, roughness, and metal and alloy strength. Silver is the noblest metal in the nanoparticles due to its wide range of bactericidal and fungicidal activities and its ability to coordinate with different ligands and macromolecules in microbial cells. Due to its antiinflammatory effect, Silver was generally used to regulate and cure the proliferation of microbials [2]. Biogenic synthesis for silver nanoparticles is generally important to produce silver nanoparticles with enhanced stability via green chemistry concepts. The production of metal nanoparticles, including biopolymers, polysaccharides, plant extracts, vitamins, and microbiology, by natural biodegradables constitutes a sustainable resource in metal nanoparticles [3-6]. 
Premanand et al. [7] studied the leaf extract of Nelumbo nucifera for silver nanoparticle synthesis. The X-ray diffraction pattern confirmed the crystalline nature of the silver nanoparticles. FTIR was used to investigate the biomolecule group's presents in the plant. The synthesized nanoparticles exhibited excellent antibacterial activity against the Gram-positive bacteria. Babu et al. [8] studied the spherical-shaped silver nanoparticles that were synthesized using bark extract of Zizyphus xylopyrus, and the size of nanoparticles ranges between 60 to 70 nm. Sathishkumar et al. [9] studied the Cinnamon zeylanicum plant and used their bark and powder for nanoparticle synthesis. Bark extract is a good source for biosynthesized silver nanoparticles than powder. In the current study, the leaf extract of Erythrina suberosa (Roxb.) was used to synthesize silver nanoparticles. A scanning electron microscope was used to determine the morphology of the nanoparticles. The reaction of the phytoconstituents that occur in E. suberusa was analyzed by Fourier-transform infrared spectroscopy. The antibacterial activity of silver nanoparticles was evaluated against different pathogenic bacteria [10].

A "green synthesis" of silver nanoparticles was done using a particular plant extract of Limonia acidissima. Silver nanoparticles were synthesized by the bioreduction of silver nitrate using different plant extract concentrations. UV-visible spectral analysis was used to confirm the formation of silver nanoparticles. The antioxidant activity was performed by the phosphomolybdenum method, and the ethanolic leaf extract of Limonia acidissima was found to possess significant antioxidant activity. The biosynthesized silver nanoparticles were further categorized by scanning electron microscopy [11]. As the reductant agent, Aloe vera leaf extract synthesized spherical shape silver nanoparticles of typical size [12]. Silver nanoparticles were successfully synthesized from $\mathrm{AgNO}_{3}$ through a simple "green route" using the latex of Jatropha curcas as a reducing as well as capping agent. Nanoparticles were characterized by X-ray diffraction analysis that showed the face cubic structure of particles [13]. Metallic silver nanoparticles with size ranged between $50 \mathrm{~nm}$ to $150 \mathrm{~nm}$ with antibacterial activity were bio-synthesized using leaf extract of an indigenous Australian plant Anigozanthos manglesii, which acted as both decreasing and capping agents [14]. The present study reports an eco-friendly, cost-efficient, rapid and easy method for synthesizing silver nanoparticles using banana peel extract. Silver nanoparticles were characterized by X-ray diffraction pattern, and a Scanning electron microscope showed the crystalline nature and spherical shaped nanoparticles. Silver nanoparticles showed effective antibacterial activity against characteristic bacterial pathogens [15].

Ramesh et al. [16]; Roy et al. [17] evaluated nanoparticles' green synthesis using Emblica officinalis and Cucumis sativus fruit extract. The biologically synthesized nanoparticles in the ranges of 8-10 nm with a spherical shape. The silver nanoparticles have significant antibacterial activity towards gram-negative bacteria, $K$. pneumonia, and grampositive bacteria, S. aureus. [18]. The biosynthetic method of nanoparticles is simple and an alternate to physical and chemical methods. By using an aqueous leaf extract of Moringa stenopetala, silver nanoparticles were synthesized by the green method. The UV-Vis spectrum showed a peak at $412 \mathrm{~nm}$. An X-ray diffraction pattern showed the face-centered cubic structure of AgNPs with an average particle size of $11.44 \mathrm{~nm}$. Synthesized AgNPs showed stronger antibacterial activity against Escherichia coli than Staphylococcus aureus [19].

Forough and Farhadi [20], using the bioreduction technique, studied the two plants' extract for the stable silver nanoparticles synthesis. The liquid extract of soap-root (Acanthe phylum bracteatum) acted as a stabilizer, and liquid extract of the manna of Hedysarum was 
used as a chemical agent. The common diameter of the prepared nanoparticles was 29-68 nm. Antibacterial activity of synthesized nanoparticles finds good results as compared to the standard drug [21].

This paper presents the synthesis of $\mathrm{AgCl}$ NPs using the aqueous extract of the outer peel of peach fruit (Prunus persica L.). The antibacterial activity is performed against five foodborne pathogenic bacteria, respectively, along with its antioxidant activity. The synthesized silver chloride nanoparticles were confirmed with a surface plasmon resonance peak at $440 \mathrm{~nm}$ by UV-Vis spectroscopy analysis. Furthermore, the morphology, elemental composition, and crystalline nature were also characterized [22]. The biosynthesized (AgNPs) were formed from $\left(\mathrm{AgNO}_{3}\right)$ through leaf extract of Prunus japonica. The XRD spectrum confirmed the presence of silver ions and the crystalline nature of synthesized AgNPs. FTIR showed the functional groups involved in the reduction of $\mathrm{Ag}^{+}$to $\mathrm{Ag}$. The synthesized nanoparticles were exhibited higher antibacterial activity and the antioxidant activity performed by (DPPH) radical scavenging assay [23].

\section{Materials and Methods}

\subsection{Plant sample collection.}

The selected plants were collected from different local areas.

\subsection{Preparation of $\mathrm{AgNO}_{3}$ solution.}

Silver nitrate solution was prepared by mixing $\mathrm{AgNO}_{3}$ salt in distilled water. Silver nitrate $\left(\mathrm{AgNO}_{3}\right)$ was acquired from Merck KGaA, 64271 Darmstadt, Germany.

\subsection{Preparation of plant extract.}

Fresh leaves of $P$. persica (L.) Batsch wild and variety plants were carefully rinsed with tap water and several times with deionized water to remove dust particles and then allowed to air dry. Dried leaves were finally cut into small pieces. For the extract preparation, 20 grams of finely cut leaves were taken into $400 \mathrm{ml}$ deionized water in a $500 \mathrm{ml}$ Erlenmeyer flask and then boiled in an oven for 15 minutes. Then extracts were allowed to cool at room temperature, and Whatman No.1 (filter paper) was used to filter the extracts. Table 1 shows the composition for the synthesis of silver nanoparticles.

\subsection{Silver nanoparticles synthesis.}

For silver nanoparticles synthesis, $100 \mathrm{ml}$ of leaf extract was taken in a flask and added $50 \mathrm{ml}$ of distilled water and a $50 \mathrm{ml}$ solution of $2 \mathrm{mM} \mathrm{AgNO}_{3}$. The reaction mixture was placed at room temperature and observed the color change; after some time, the reaction mixture's color was changed from yellow to brown, and this color change was the first indication of silver nanoparticles synthesis. UV-Visible spectroscopy was used for further confirmation of silver nanoparticles.

Table 1. The composition for the synthesis of silver nanoparticles.

\begin{tabular}{l|c|c|c} 
Parts of plants & Plant extracts & Deionized water & AgNO $_{3}$ solution \\
\hline Leaves of Prunus persica wild & $100 \mathrm{ml}$ & $50 \mathrm{ml}$ & $50 \mathrm{ml}$ \\
\hline Leaves of Prun persica variety & $100 \mathrm{ml}$ & $50 \mathrm{ml}$ & $50 \mathrm{ml}$
\end{tabular}




\subsection{Separation of silver nanoparticles.}

The grayish-brown and dark brown solution was centrifuged at $15000 \mathrm{rpm}$ for 5 minutes into the Eppendorf tube for the separation of synthesized silver nanoparticles. The centrifuging and re-dispersing process was repeated three times with distilled water to remove unreacted phytochemicals from the AgNPs [24]. Separated silver nanoparticles were washed with acetone for further purification and characterized by different techniques.

\subsection{Characterization.}

2.6.1. UV-Visible spectral analysis.

The optical property of samples was examined by using UV-Vis (DRS). Spectra of nanomaterials were recorded in the collection of $300 \mathrm{~nm}-700 \mathrm{~nm}$ range. The spectrograph of the prepared material was recorded concerning water at different time intervals.

2.6.2. X-Ray diffraction analysis.

$\mathrm{X}$-ray diffraction (instrument name) analysis of silver nanoparticles was carried out with a Rigaku X-ray diffractometer with $\mathrm{Cu} \mathrm{K} \alpha$ radiation over a $2 \theta$ to examine possible sample crystallinity.

2.6.3. Fourier transforms infrared spectroscopy (FTIR) analysis.

The change in functional groups of materials was analyzed by FTIR on a Bruker (Parkin Elmer 100) instrument by the ATR method in the range $100-4000 \mathrm{~cm}^{-1}$ [25]. To check the main functional groups of the material prepared from Prunus persica (wild and variety Fourier transform infrared spectroscopic analysis was done.

\subsection{Antibacterial activity of silver nanoparticles.}

The antibacterial activity was done on synthesized silver nanoparticles against grampositive (Staphylococcus aureus) and gram-negative (Pseudomonas aeruginosa and Klebsiella pneumonia) by using the Disc-diffusion method [26]. All the bacteria were obtained from C. M. H. Muzaffarabad. The bacterial cultures were prepared in the laboratory using nutrient agar medium and then incubated for 24 hours at $37{ }^{\circ} \mathrm{C}$. Test tubes, disc, Petri plates, nutrient agar medium, distilled water, and loops were sterilized in an autoclave at $121{ }^{\circ} \mathrm{C}$ for 15 minutes. 10 $\mathrm{ml}$ of water was taken in a sterile test tube. A loop of the bacterium was inoculated in distilled water under aseptic conditions. Each overnight bacterial inoculum $(100 \mu \mathrm{l})$ was spread on sterile Petri plates containing nutrient Agar medium and rotated gently to mix inoculum in medium and were allowed to solidify at room temperature. The $10 \mathrm{mg}$ silver nanoparticles were dispersed in $1 \mathrm{ml}$ of distilled water. Sterile disc of $6 \mathrm{~mm}$ containing silver nanoparticles (plant extract, silver nitrate, and ampicillin) were placed in Petri plates and again incubated at $37{ }^{\circ} \mathrm{C}$ for 24 hours. The zone of inhibition was measured with the help of the meter-scale after 24 hours. This activity was repeated three times for calculating the mean value in millimeters.

\subsection{Antioxidant activity of silver nanoparticles.}

1, 1-diphenyl-2-picrylhydrazil (DPPH) radical scavenging assay was used to calculate the antioxidant activity using a [27] method. DPPH radical scavenging assay is an effective 
method that has been used to control the antioxidant ability of many antioxidants. DPPH is a stable free radical that has been widely used to evaluate the free-radical scavenging activity of antioxidants. The reaction consisted of AgNPs, standard DPPH solution, methanol, and extracted with different concentrations of both $(25,50$, and $100 \mu \mathrm{g} / \mathrm{mL})$ were transferred in a labeled test tube for a sample and blank reading, mixed properly, and retained for 30 minutes. The experiments were performed three times. UV-Vis spectroscopy was used to read the absorbance at $517 \mathrm{~nm}$ against blank reading. To calculate the percentage scavenging activity, the following formula was used:

\section{DPPH scavenging assay $(\%)=[(\mathrm{A} 0-\mathrm{A} 1) / \mathrm{A} 0] \times 100$}

Hence A0 is the absorbance of the control and A1, is the absorbance of the AgNPs and plant extract at $30 \mathrm{~min}$. Microsoft Excel software was used to calculate the 50 percent inhibition (IC50) for each concentration.

\section{Results and Discussion}

The synthesis, characterization, and application of a biologically fabricated nanostructure have significant importance in nanotechnology. The present study was shown a simple, cost-effectively, and environmentally friendly method of silver nanoparticles by mixing leaf extract of Prunus persica wild and variety to the $\mathrm{AgNO}_{3}$ solution.

\subsection{Silver nanoparticles synthesis.}

When aqueous $\mathrm{AgNO}_{3}$ solution was mixed with plant extracts, the silver ions were condensed in solution, silver nanoparticles' primary formation. The initial color of leaf extracts of Prunus persica wild and variety was dark yellow and pale yellow, respectively, then it started to change and finally attained dark brown in case of Prunus persica wild and greyish brown in case of Prunus persica variety when treated with $\mathrm{AgNO}_{3}$ solution. Prunus persica wild took 10 minutes, while Prunus persica variety took 15 minutes to synthesize silver nanoparticles. These color changes indicate the reduction of silver ions to silver nanoparticles.

\subsection{UV-Vis spectral analysis.}

UV-visible spectroscopy had been used to confirm the reduction of silver ions to silver nanoparticles. UV-Vis spectrograph of silver nanoparticles had been observed with different time intervals and water used as a reference between $300 \mathrm{~nm}-700 \mathrm{~nm}$. Surface plasmon resonance, which is one of the important optical properties due to combined electron vibration around the particle surface model, was exhibited by silver nanoparticles formed in the solution. When Prunus persica leaves (wild and variety) were mixed with silver ion solution, no absorption peak was observed. The UV-Vis spectra recorded a strong surface plasmon resonance band for Prunus persica (wild) leaf extract whose intense peak occurred at $467 \mathrm{~nm}$ and $492 \mathrm{~nm}$ (Fig. 1). In contrast, the surface plasmon resonance bands for Prunus persica (variety) showed absorbance peak at $462 \mathrm{~nm}$ and then $491 \mathrm{~nm}$ (Fig. 2). The observed peaks broaden in all the spectra, which indicates the polydispersed nature of silver nanoparticles. 


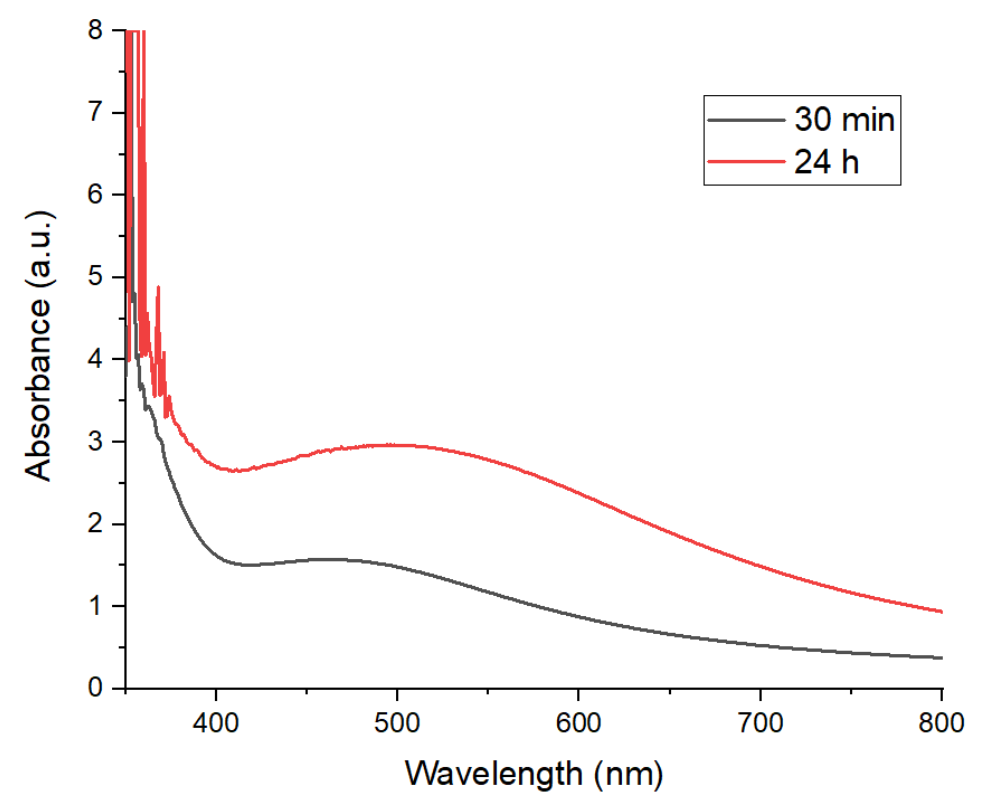

Figure 1. UV-Visible absorption spectra of synthesized silver nanoparticles from Prunus persica variety leaf extract.

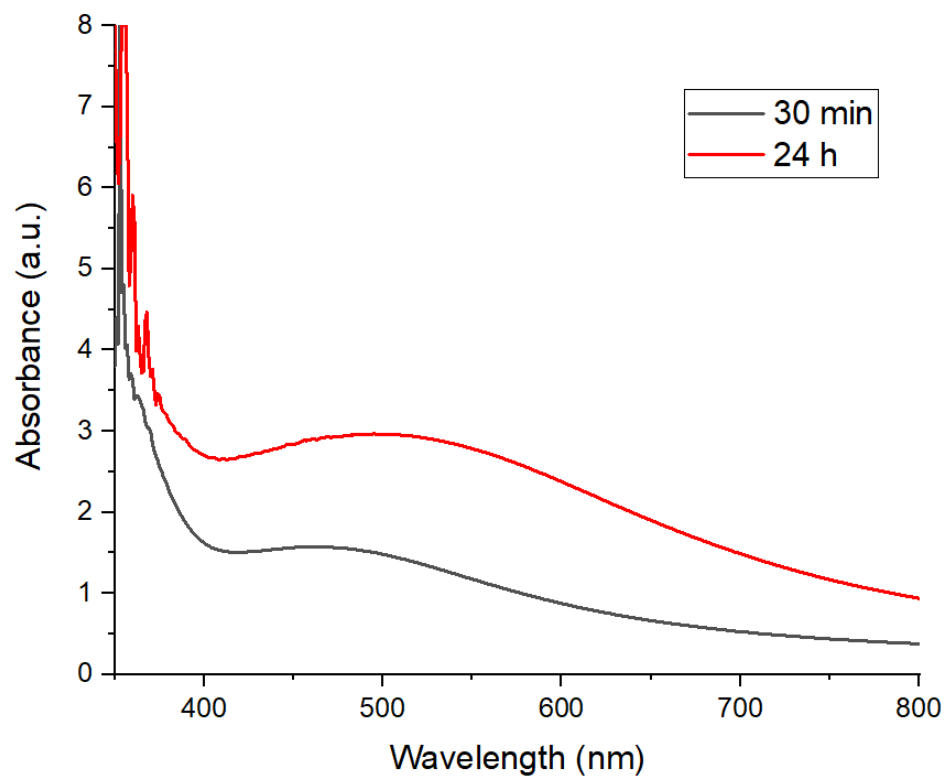

Figure 2. UV-Visible absorption spectra of synthesized silver nanoparticles from Prunus persica variety leaf extract.

\subsection{Fourier transmission infrared spectroscopy.}

The double role of the plant extract both as a reducing and capping agent and presence of some functional groups was confirmed by FTIR analysis of silver nanoparticle It was observed that the silver nanoparticles obtained from leaf extract of Prunus persica wild expressed the absorption peaks at $516.89 \mathrm{~cm}^{-1}, 1024.13 \mathrm{~cm}^{-1}, 1068.49 \mathrm{~cm}^{-1}, 1118.64 \mathrm{~cm}^{-1}$, $1161.07 \mathrm{~cm}^{-1}, 1375.15 \mathrm{~cm}^{-1}, 1608.52 \mathrm{~cm}^{-1}, 1652.88 \mathrm{~cm}^{-1}, 1679.88 \mathrm{~cm}^{-1}, 1730.03 \mathrm{~cm}^{-1}, 1988.47$ $\mathrm{cm}^{-1}, 2073.33 \mathrm{~cm}^{-1}, 2898.81 \mathrm{~cm}^{-1}, 3458.13 \mathrm{~cm}^{-1}$. The absorption peaks at $516.89 \mathrm{~cm}^{-1}$ for $\mathrm{C}-\mathrm{Br}$ stretch, $1024.13 \mathrm{~cm}^{-1}$ could be assigned for $\mathrm{C}-\mathrm{O}$ stretch, whereas the peak at $1068.49 \mathrm{~cm}^{-1}$ assigned to the $\mathrm{C}-\mathrm{OH}$ bond of aromatic compounds. The observed peak at $1679.88 \mathrm{~cm}^{-1}$ resulted from aryl ketone stretch, the peaks at $1118.64 \mathrm{~cm}^{-1}$ and $1161.07 \mathrm{~cm}^{-1}$ corresponds to C-N or C-O stretching alcohols. A peak at $1988.47 \mathrm{~cm}^{-1}$ for $\mathrm{C}=\mathrm{C}$ asymmetric stretch, 1608.59 
$\mathrm{cm}^{-1}$ assigned to $\mathrm{C}=\mathrm{C}$ aromatic stretch. The absorption peaks at $1375.1 \mathrm{~cm}^{-1}$ can be allocated to the presence of $\mathrm{C}-\mathrm{O}$ stretching is carboxyl. The absorption peaks $1652 \mathrm{~cm}^{-1}$ and 1730.03 $\mathrm{cm}^{-1}$ correspond to amide $\mathrm{C}=\mathrm{O}$ and $\mathrm{C}=\mathrm{O}$ stretching of the carbonyl group in ketones, aldehydes, and carboxylic acid. A peak at $2073 \mathrm{~cm}^{-1}$ can be given to the alkyne group. A wideband at 3458 $\mathrm{cm}^{-1}$ is due to the N-H stretching, and $2898.81 \mathrm{~cm}^{-1}$ is assigned for $-\mathrm{CH}_{2}$ or $-\mathrm{CH}_{3}$ functional groups (Fig. 3).

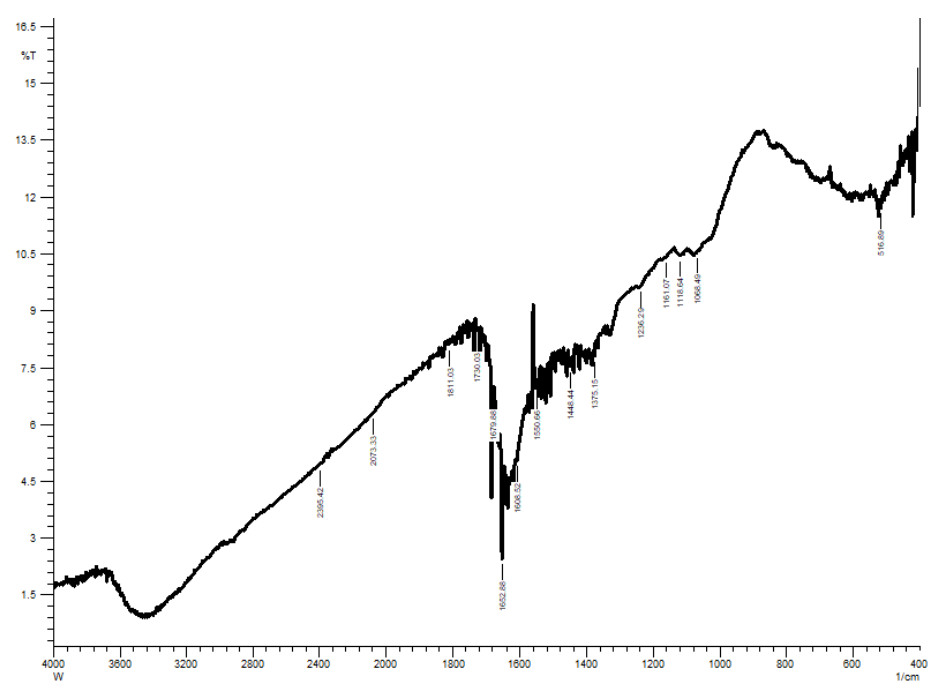

Figure 3. FTIR spectrum of air-dried powder of Prunus persica wild leaf extract.

The FTIR spectra obtained by the leaf extract of Prunus persica variety showed absorption peaks was at $557.39 \mathrm{~cm}^{-1}, 688.54 \mathrm{~cm}^{-1}, 727.11 \mathrm{~cm}^{-1}, 748.33 \mathrm{~cm}^{-1}, 1033.77 \mathrm{~cm}^{-1}$, $1051.13 \mathrm{~cm}^{-1}, 1193.85 \mathrm{~cm}^{-1}, 1342.36 \mathrm{~cm}^{-1}, 1608.52 \mathrm{~cm}^{-1}, 2335.64 \mathrm{~cm}^{-1}, 2848.67 \mathrm{~cm}^{-1}, 2921.96$ $\mathrm{cm}^{-1}$. The peaks at $557 \mathrm{~cm}^{-1}$ and $688.54 \mathrm{~cm}^{-1}$ indicates the $(\mathrm{C}-\mathrm{Br})$ stretch of Alkyl halide. The peaks at $727.19 \mathrm{~cm}^{-1}$ and $748.33 \mathrm{~cm}^{-1}$ were assigned for $\mathrm{C}-\mathrm{H}$ stretching and $\mathrm{C}-\mathrm{H}$ alkenes stretch. Further, peaks assigned at $1342.36 \mathrm{~cm}^{-1}$ and $1051 \mathrm{~cm}^{-1}$ suggest the amine and hydroxyl groups of alcohol. $1193.85 \mathrm{~cm}^{-1}$ assigned to $\mathrm{C}-\mathrm{N}$ amines stretch, $1608.52 \mathrm{~cm}^{-1}$ assigned to $\mathrm{C}=\mathrm{C}$ aromatic stretch, $2335.64 \mathrm{~cm}^{-1}$ specified for C-H stretching. A peak at $2848.67 \mathrm{~cm}^{-1}$ corresponds to $\mathrm{C}-\mathrm{H}$ vibration. The observed peak at $2921.96 \mathrm{~cm}^{-1}$ is assigned for the $\mathrm{C}-\mathrm{H}$ stretching of the alkane amide I band (Fig. 4).

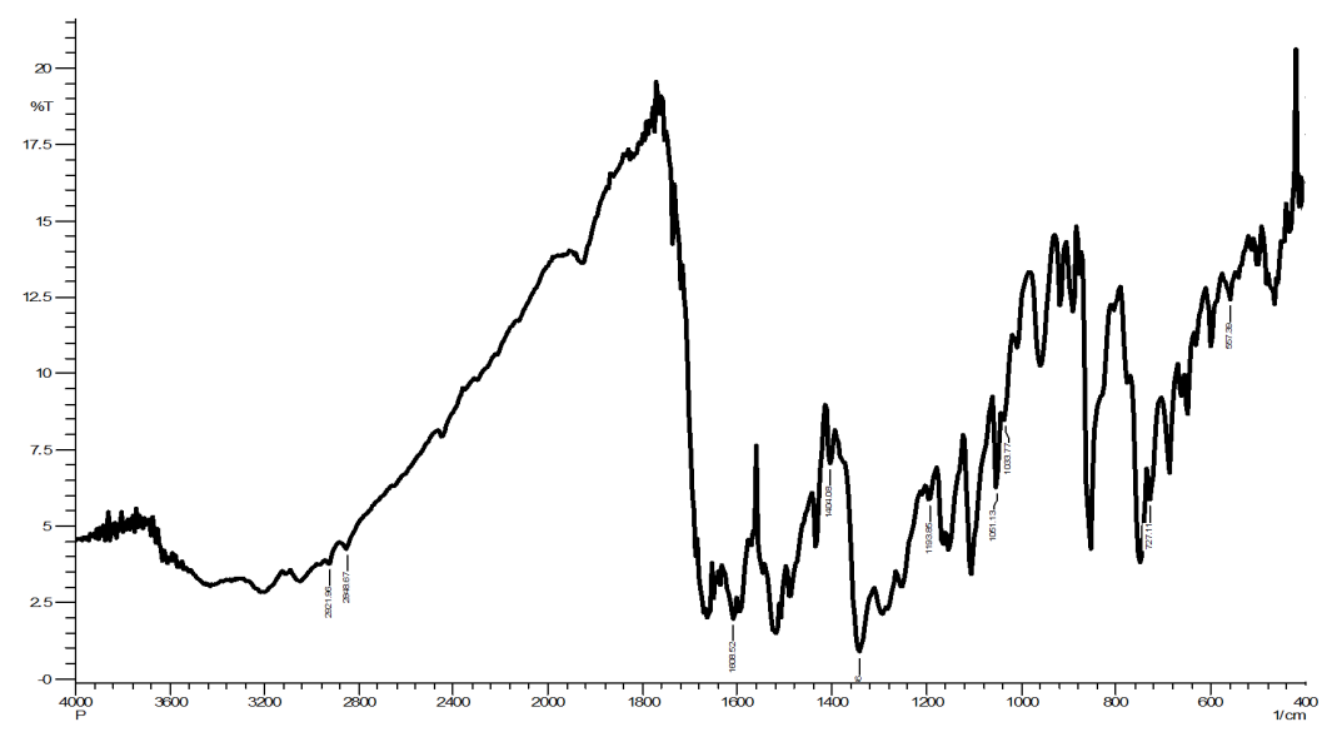

Figure 4. FTIR spectrum of air-dried powder of Prunus persica variety leaf extract. 


\subsection{XRD analysis.}

$\mathrm{X}$-Ray analysis was used to confirm the presence of silver nanoparticles with crystalline nature. By using an X-Ray machine with radiations having $0.15 \mathrm{~nm}$ wavelength of X-rays and in the $2 \theta$ range between $10^{\circ}$ to $90^{\circ}$ at Nanoscience and technology department (NS\&TD), National Centre for Physics (NCP), Islamabad, Pakistan to study the purity, interlayer spacing, and crystallinity of the synthesized nanomaterial. To calculate the Crystalline size of the nanoparticle was calculated by using Debye-Scherrer's equation as below;

$$
\mathrm{D}=\frac{K \lambda}{\beta \cos \theta}
$$

Where " $D$ " represents domain size of crystallite, " $\lambda$ " represents the wavelength of X-rays used $(0.15 \mathrm{~nm})$, " $\mathrm{K}$ " stands for Scherrer's constant, " $\theta$ " represent Bragg's angle, and " $\beta$ " is the width of diffraction peak and is calculated as full width half maximum (FWHM).

XRD spectrum showed various peaks that may be indexed based on a face-centered cubic structure of silver. Fig 5 shows the XRD spectrum of Ag nanoparticles synthesized using leaf extract. Fig 6 shows the XRD spectrum of Ag nanoparticles synthesized using leaf extract of Prunus persica variety. The comparison of XRD pattern of synthesized material with standard confirmed the nanocrystal formation as evidenced through diffraction peaks observed at $2 \theta=38.10^{\circ}, 44.33^{\circ}, 64.32^{\circ}, 77.47^{\circ}$ corresponds to (111), (200), (220), (311) respectively, while the XRD pattern for Prunus persica variety shown 2 theta angles values at $37.93^{\circ}, 44.18^{\circ}$, $64.36^{\circ}, 77.31^{\circ}$ due to reflection from $111^{\circ}, 200^{\circ}, 220^{\circ}, 311^{\circ}$ planes, showing the absence of impurity, good crystallinity homogeneous composition of Silver nanoparticles, indicating the formation of nanoparticles of $\mathrm{Ag}$. The average crystallite size calculated from the XRD spectrum was found approximately about $18.09 \mathrm{~nm}$ for Prunus persica wild (Table 2) and $17 \mathrm{~nm}$ for Prunus persica variety (Table 3 ). The crystalline size of $17 \mathrm{~nm}$ to $18 \mathrm{~nm}$ demonstrates that the AgNPs synthesized using the "green method" were nanocrystalline. The broadening of peaks showed that other biological macromolecules are also present in the plants.

Table 2. Determination of the crystalline size of AgNP's using Debye-Scherrer's equation.

\begin{tabular}{l|c|c|c|c} 
Peaks & 20 Value & FWHM & $\boldsymbol{\Theta}$ & $\mathbf{D}=\mathbf{K} \boldsymbol{\lambda} / \boldsymbol{\beta} \cdot \cos \boldsymbol{\theta}$ \\
\hline $\mathbf{1 1 1}$ & 38.10 & 0.5395 & 0.9799 & 15.69 \\
\hline $\mathbf{2 0 0}$ & 44.33 & 0.7343 & 0.9849 & 11.47 \\
\hline $\mathbf{2 2 0}$ & 64.32 & 0.5526 & 0.7359 & 20.41 \\
\hline $\mathbf{3 1 1}$ & 77.48 & 0.6558 & 0.5097 & 24.82
\end{tabular}

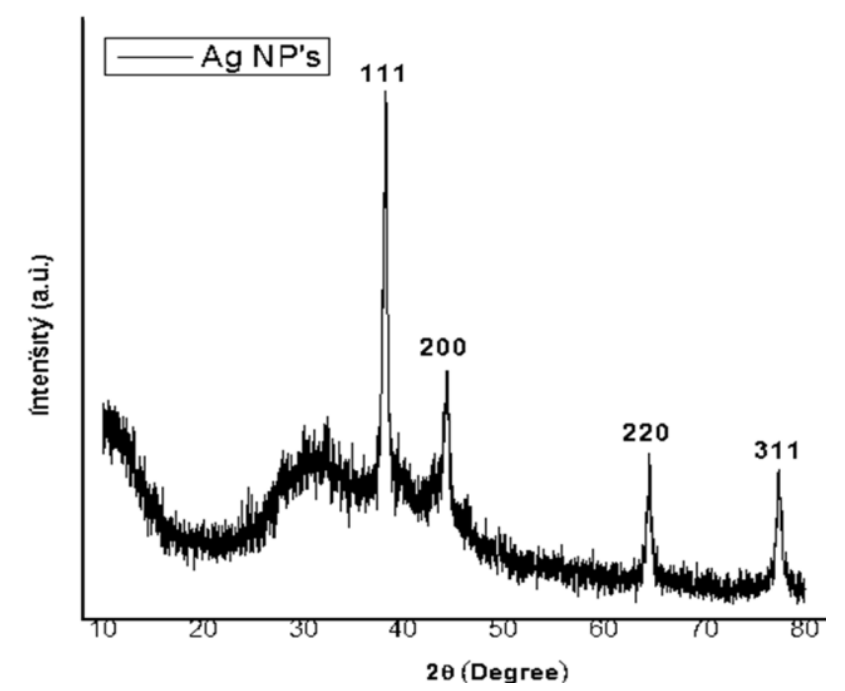

Figure 5. XRD spectrum of Ag nanoparticles synthesized using leaf extract. 
Table 3. Determination of the crystalline size of AgNP's using Debye-Scherrer's equation.

\begin{tabular}{l|c|c|c|c} 
Peaks & 20 Value & FWHM & $\boldsymbol{\Theta}$ & $\mathbf{D}=\mathbf{K} \boldsymbol{\lambda} / \boldsymbol{\beta} \cos \boldsymbol{\theta}$ \\
\hline $\mathbf{1 1 1}$ & 37.93 & 0.4723 & 0.9559 & 18.24 \\
\hline $\mathbf{2 0 0}$ & 44.18 & 0.6298 & 0.9403 & 14.06 \\
\hline $\mathbf{2 2 0}$ & 64.46 & 0.6387 & 0.8745 & 15.74 \\
\hline $\mathbf{3 1 1}$ & 77.23 & 0.0654 & 0.8216 & 22.62
\end{tabular}

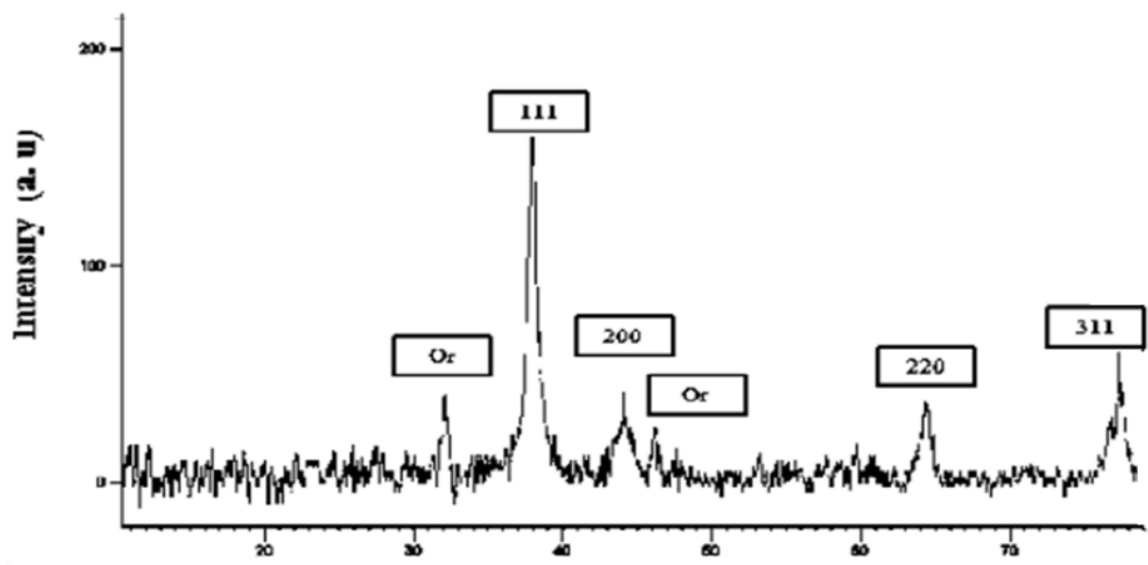

Figure 6. XRD spectrum of Ag nanoparticles synthesized using leaf extract of Prunus persica variety.

\subsection{Antibacterial assay.}

Photosynthesized silver nanoparticles of Prunus persica wild and variety were used to evaluate the antibacterial activity against different bacteria of (Staphylococcus aureus, Pseudomonas aeruginosa, and Klebsiella pneumonia) by using the Disc-diffusion method. To inhibit the growth of tested bacteria, the aqueous leaf extract of Prunus persica (wild and variety), aqueous extract mediated silver nanoparticles, $\mathrm{AgNO}_{3}$ (salt), and ampicillin were used. The inhibition growth results were shown in Table 4 and Table 5 regarding the mean plus standard error. Fig 7 shows the zones of inhibition of Prunus persica (wild and variety) mediated silver nanoparticles. The silver nanoparticles were synthesized from the leaf extract of Prunus persica (wild) showed maximum inhibition zone against pseudomonas aeruginosa $(10.33 \pm 0.57)$. The minimum zone of inhibition was found to be Staphylococcus aureus ( $8 \pm$ 2). Whereas the synthesized silver nanoparticles from the leaf extract of Prunus persica (variety) showed a higher zone of inhibition against Staphylococcus aureus (12.33 \pm 2.08 ), and the least zone of inhibition was found towards klebsiella pneumonia $(8.66 \pm 0.57)$. At the same time, modest activity was revealed by the Pseudomonas aeruginosa $(10 \pm 5.85)$. The variation among the zone of inhibition of different bacterial strains is due to the bacterial cell wall composition difference. The Gram-positive bacteria have a thick peptidoglycan layer as compared to the Gram-negative bacteria is thinner. The aqueous extract showed good antibacterial activity towards the Pseudomonas aeruginosa and Klebsiella pneumonia. Positive control showed near to maximum inhibition zone for all inoculums against klebsiella pneumonia $(8.33 \pm 2.51)$. Fig 8 shows the mean zone of inhibition of Prunus persica wild mediated silver nanoparticles against test bacteria. Fig 9 shows the mean zone of inhibition of Prunus persica variety mediated silver nanoparticles against test bacteria. 


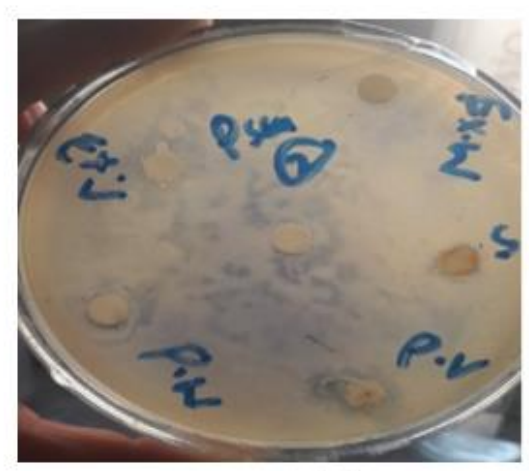

(a)

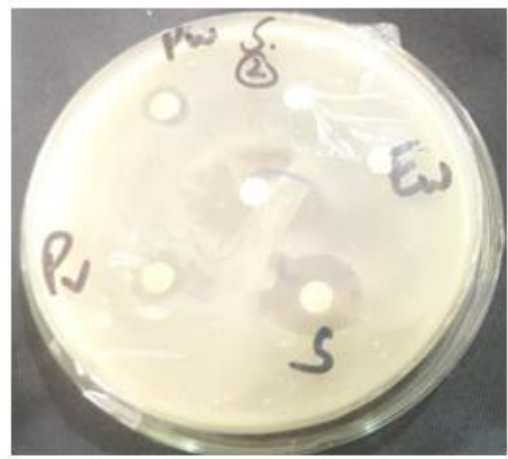

(b)

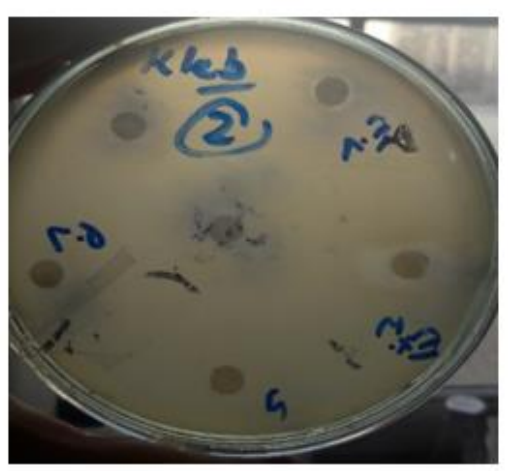

(c)

Figure 7. Zones of inhibition of Prunus persica (wild and variety) mediated silver nanoparticles: (a) shows the results of Staphylococcus aureus, (b) shows the results of Pseudomonas aeruginosa, and (c) shows the results of Klebsiella pneumonia. Where, $\mathrm{Ew}=$ extract of wild plant, $\mathrm{Ev}=$ extract of variety plant, $\mathrm{Pw}=$ silver nanoparticles from wild plant, $\mathrm{Pv}=$ silver nanoparticles from variety plant, $\mathrm{S}=\mathrm{AgNO}_{3}$.

Table 4. Antibacterial assays of Prunus persica wild mediated silver nanoparticles.

\begin{tabular}{l|c|c|c|c} 
Bacterial spp & Aqueous extract & AgNPs & AgNO $_{3}$ & Control \\
\hline S.aureus & $6.66 \pm 1.15$ & $8 \pm 2$ & $15 \pm 4.35$ & $25 \pm 8.18$ \\
\hline Pseudomonas & $9.33 \pm 3.511$ & $10.33 \pm 0.577$ & $10.33 \pm 1.527$ & $9.33 \pm 3.511$ \\
\hline Klebsiella & $9 \pm 5.196$ & $8.33 \pm 2.516$ & $11 \pm 2.645$ & $7.66 \pm 2.886$
\end{tabular}

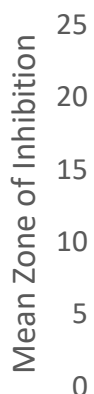

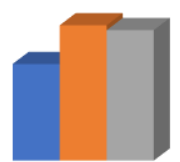

Aqueous extract

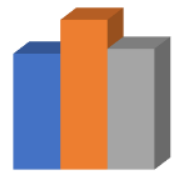

AgNPs

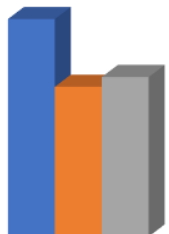

AgNO3

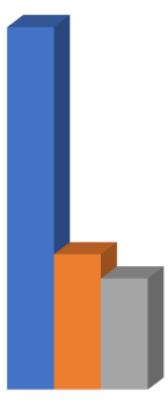

Control

- Staphylococcus aureus aseudomonas aeruginosa Klebsiella pneumoneae

Figure 8. Mean zone of inhibition of Prunus persica wild mediated silver nanoparticles against test bacteria.

Table 5. Antibacterial assays of Prunus persica variety mediated silver nanoparticles.

\begin{tabular}{l|c|c|c|c} 
Bacterial spp. & Aqueous extract & AgNPs & AgNO $_{3}$ & Control \\
\hline S.aureus & $7.66 \pm 2.886$ & $12.33 \pm 2.081$ & $13.66 \pm 3.511$ & $22.66 \pm 8.326$ \\
\hline Pseudomonas & $9.66 \pm 4.041$ & $10.33 \pm 5.859$ & $11.33 \pm 2.516$ & $7.66 \pm 2.886$ \\
\hline Klebsiella & $9 \pm 1.732$ & $8.66 \pm 0.577$ & $10.66 \pm 1.154$ & $8.33 \pm 4.041$
\end{tabular}




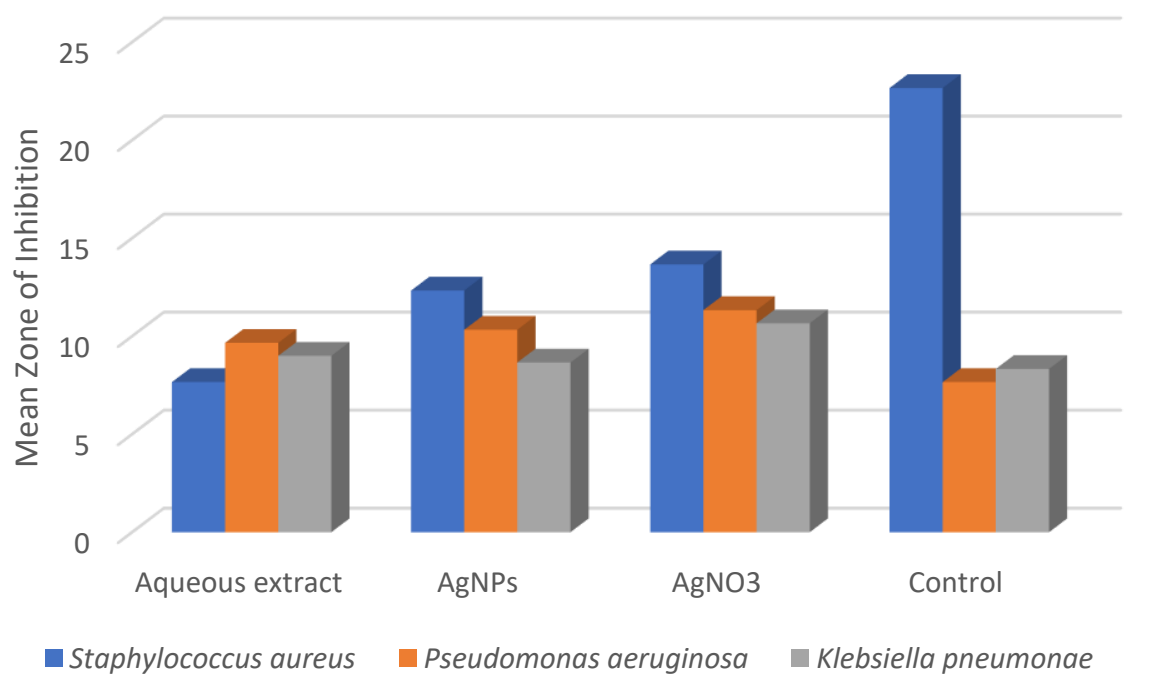

Figure 9. Mean zone of inhibition of Prunus persica variety mediated silver nanoparticles against test bacteria.

\subsection{Antioxidant assay.}

An antioxidant may be explained as "any material when present at low concentrations, compared with those of the oxidizable substrate, inhibits the oxidation of that substrate". DPPH is a free radical; it becomes changed into a stable molecule [28].

Table 6. Antioxidant activity of silver nanoparticles.

\begin{tabular}{l|c|c|c|c}
\multirow{2}{*}{ Sample } & \multicolumn{3}{|c|}{ Percentage Scavenging activity } & \multirow{2}{*}{ IC50 } \\
\cline { 2 - 4 } & 25 & 50 & 100 & 0.114346 \\
\hline Wild Extract & 32.923 & 38.412 & 42.025 & 0.0573 \\
\hline Wild Extract NPs & 37.782 & 40.602 & 42.782 & 0.07262 \\
\hline Variety Extract & 46.558 & 39.081 & 46.558 & 0.123466
\end{tabular}

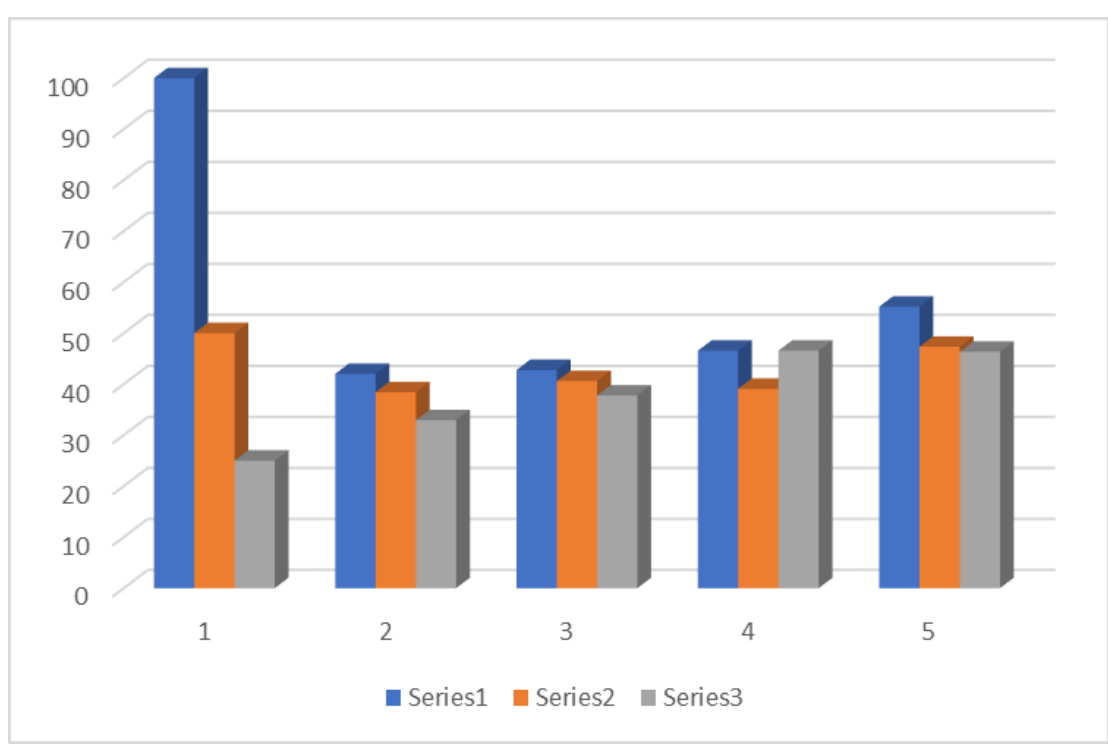

Figure 10. The percentage of Radical scavenging activity.

The antioxidant activity was done on synthesized AgNPs and plant extract of Prunus persica wild and variety. DPPH radical scavenging method has been used to measure the antioxidant activity because it is a quick and reliable method. The DPPH free radical scavenging activity was measured by using a spectrophotometer to record reading at $517 \mathrm{~nm}$. A histogram presents the results in Fig 10. The results showed that the IC50 value of wild- 
synthesized AgNPs exhibited the highest (0.0573) value, followed by (0.07262) various AgNPs. Therefore, the highest scavenging activity was observed in wild extract (0.114346) and variety extract (0.123466), as shown in Table 6 . The antioxidant activity of nanoparticles and plant extract increases with an increase in concentrations $(25-100 \mathrm{~g} / \mathrm{mL})$. The greater antioxidant capacity of AgNPs can be attributed due to the presence of some of the phytochemicals of Prunus persica L. in the nanoparticles as capping agents. Some phytochemicals are flavonoids with several hydroxyl groups.

\subsection{Discussion.}

In the present study, we prepared silver nanoparticles from $2 \mathrm{mM} \mathrm{AgNO}_{3}$ solution and leaf extract of Prunus persica (L.) Batsch (wild and variety) and their characterization are done using different techniques UV-Vis Spectroscopy, FTIR, SEM, and XRD. The plant 1material contains certain organic compounds that act as reducing, capping, and stabilizing agents. When leaf extract was mixed with an aqueous $\mathrm{AgNO}_{3}$ solution, it started to change color. The initiation of color change was observed after 10 to 15 minutes for Prunus persica L. (Batsch) wild and variety leaf extract, respectively. The color changes from pale yellow to dark brown and then dark yellow to grayish brown were due to the excitation of surface plasmon vibration in the silver nanoparticles formed in the reaction mixture [29]. The color change indicated the reduction of silver ions to silver nanoparticles [30].

$\mathrm{UV}-\mathrm{Vis}$ spectroscopy is a technique used to establish the silver nanoparticles in an aqueous solution. The surface plasmon band of silver nanoparticles appeared in a range of 300 $\mathrm{nm}$ to $700 \mathrm{~nm}$ [31]. The color change of the colloidal solution was followed by UV-Vis spectroscopy, which confirmed the reduction of silver ions to silver Nano size particles. Surface Plasmon resonance occurred at $491 \mathrm{~nm}$ of reaction solution containing leaf extract of Prunus persica wild and variety. This result was near the work where the absorption peak was observed at $475 \mathrm{~nm}$ for a silver solution having leaf extract of Memecylon edule [32]. Silver nanoparticles in the reaction solution containing leaf extract of Prunus persica wild and variety showed resonance band at $462 \mathrm{~nm}$, which was closely related to results obtained by [33]. Simultaneously, the silver nanoparticles using parthenium leaf extract showed an absorption spectrum at $460 \mathrm{~nm}$.

FTIR study was carried out to study the functional groups of Prunus persica wild and variety extract. Silver nanoparticles were prepared to determine unknown materials by producing an infrared absorption spectrum that identifies types of chemical bonds in a molecule that acts as a reducing agent. The FTIR analysis of the silver nanoparticles formed from the plant extracts confirmed that the plant extract's biomolecules were responsible for reducing, capping, and stabilizing silver nanoparticles. In the case of Prunus persica, wild aqueous extract peaks appeared at $1068(\mathrm{C}-\mathrm{O})$ stretching from alcohol, carboxylic acid, and $(\mathrm{C}-\mathrm{N})$ stretching vibration of amine [34]. The peak at $1375.15 \mathrm{~cm}^{-1}$ attributed to $-\mathrm{OH}$ or $\mathrm{C}-\mathrm{N}$ stretching of aromatic amine [35]. The peak at $1730.03 \mathrm{~cm}^{-1}$ corresponds to $(-\mathrm{C}=\mathrm{O})$ stretching of the carbonyl group in ketones, aldehydes, and carboxylic acid [36]. Broadband between $3458 \mathrm{~cm}^{-1}$ is due to the N-H stretching. The band at $1652 \mathrm{~cm}^{-1}$ corresponds to amide $\mathrm{C}=\mathrm{O}$ stretching, and a peak at $2073 \mathrm{~cm}^{-1}$ can be assigned to the alkyne group [12,37]. $1118.64 \mathrm{~cm}^{-1}$ and $1608.59 \mathrm{~cm}^{-1}$ corresponds to $\mathrm{C}-\mathrm{N}$ amines and $\mathrm{C}=\mathrm{C}$ aromatic stretch. The peak at 2898.81 $\mathrm{cm}^{-1}$ is assigned to the stretching vibrations of the $-\mathrm{CH}_{2}$ and $-\mathrm{CH}_{3}$ functional groups [38].

The FTIR spectrum of silver nanoparticles synthesized from the leaf extract of Prunus persica variety showed peaks at $727.19 \mathrm{~cm}^{-1}$, corresponds to $\mathrm{C}-\mathrm{H}$ stretching strong aromatic 
mono-substituted benzene [39]. A wide and strong peak with maximum intensity at $557 \mathrm{~cm}^{-1}$ [40]. Some other peaks observed at $1606.59 \mathrm{~cm}^{-1}, 1193.85 \mathrm{~cm}^{-1}$, and $748 \mathrm{~cm}^{-1}$ were assigned to $\mathrm{C}=\mathrm{C}$ aromatic stretch, $\mathrm{C}-\mathrm{N}$ amines stretch, and $\mathrm{C}-\mathrm{H}$ alkenes stretch [41] and $2848.67 \mathrm{~cm}^{-1}$ belongs to the $\mathrm{C}-\mathrm{H}$ stretching vibration of $-\mathrm{CH} 3$ and $-\mathrm{CH} 2$ groups [42]. A peak observed at $2921.96 \mathrm{~cm}^{-1}$ is due to the $\mathrm{C}-\mathrm{H}$ stretching of the alkane amide I band of proteins [43]. The peak at $1051.13 \mathrm{~cm}^{-1}$ assigned to $\mathrm{C}-\mathrm{O}$ stretching from alcohol, carboxylic acid, and $\mathrm{C}-\mathrm{N}$ stretching vibration of amine. The peak at $1033 \mathrm{~cm}^{-1}$ corresponds to the $\mathrm{C}-\mathrm{O}$ stretching of alcohols, carboxylic acids, or C-N stretching of aliphatic amines [34].

The XRD analysis was used for determining the size, chemical composition, and crystalline nature of silver nanoparticles obtained from leaf extract of Prunus persica (L.) Batsch wild and varied. The X-ray pattern of silver nanoparticles of Prunus persica wild corresponding to Fcc structure of silver at the scanning of $10^{\circ}$ to $90^{\circ}$ along with the broad peaks observed at $38.10^{\circ}, 44.33^{\circ}, 64.32^{\circ}, 77.47^{\circ}$ corresponding to (111), (200), (220), (311) planes respectively, with an average particle size of $18.09 \mathrm{~nm}$. In the case of Prunus persica variety silver nanoparticles, the XRD calculation observed peaks at $37.93^{\circ}, 44.18^{\circ}, 64.36^{\circ}$, and $77.31^{\circ}$, corresponding to $111^{\circ}, 200^{\circ}, 220^{\circ}, 311^{\circ}$ planes. The average particle size of 17 $\mathrm{nm}$. The plane of diffraction shows the crystalline nature of silver nanoparticles. Similar particle size of $18 \mathrm{~nm}$ was reported by [44].

The photosynthesized silver nanoparticles from plant extract were proved to be toxic against different bacterial strains. Silver nanoparticles do not remain nano-size when they together in a cluster become larger and more efficient when they come in contact with natural liquid like water [45]. The antibacterial effect was observed against Gram-positive (S. aureus) bacterial strains and Gram-negative (Pseudomonas aueroginosa, Klebsiella pneumonia) bacterial strains using the Disc Diffusion method [26]. Values of the Inhibition zone were observed by AgNPs, aqueous plant extract, $\mathrm{AgNO}_{3}$, and positive control. Silver nanoparticles and $\mathrm{AgNO}_{3}$ have shown good and almost similar antibacterial activity against Gram-positive and Gram-negative bacteria. Due to their small size and large surface area, silver nanoparticles have shown great contact with bacteria. They can easily reach the nuclear wall of bacteria $[46,47]$. Numerous investigations estimated that AgNPs, when coming in contact with bacteria, could attach to the cell membrane surface, affect the respiratory function of the membranebound enzymes of the cell, and disturbed the morphology to increase permeability. As compared to the larger AgNPs, smaller Ag NPs showed a high bactericidal effect due to the large surface area for interface [48]. Some investigators believed that Ag NPs release silver ions on the surface, mainly responsible for bacterial strains' inhibitory effect [49]. AgNPs showed the highest antibacterial activity against Gram-positive bacteria (Staphylococcus aureus 12.33), which was followed by the Gram-negative bacteria (Pseudomonas aueroginosa 10.33 and klebsiella pneumonia 8.33) [50]. The aqueous extract of both Prunus persica wild and various plants was effective against Gram-negative bacteria (Pseudomonas aueroginosa) [51]. The synthesized AgNPs showed good antibacterial activity as compared to the plant extract [52]. To calculate the antioxidant activity 1, 1-diphenyl-2-picrylhydrazil (DPPH) radical scavenging assay method was used [27]. DPPH is a stable free radical that has been widely used to evaluate the free-radical scavenging activity of antioxidants [53]. The nanoparticles and extract showed DPPH free radical scavenging activity in a concentration range of $25-100 \mu \mathrm{l} / \mathrm{ml}$, and its inhibition ranged from 32.923-55.382 \%. The IC50 value was measured for both plant extract and synthesized nanoparticles, which is required for $50 \%$ inhibition of the free radical DPPH, was determined. The wild synthesized AgNPs showed the 
highest antioxidant activity, followed by various AgNPs compared to the wild and variety extract.

\section{Conclusions}

In the present study, silver nanoparticles were synthesized using leaf extract of Prunus persica L. Batsch (wild and variety) at room temperature. UV-Vis spectroscopy showed the broad peaks in the range of 460- $492 \mathrm{~nm}$ that confirmed the variation in particle size and polydispersed nature of AgNPs. The average nanoparticles size was found to be $18 \mathrm{~nm}$ and 17 $\mathrm{nm}$ that was confirmed by the X-Ray Diffraction Analysis. FTIR determined the biomolecules such as alkanes, alkenes, amides, carboxylic groups in the material. The antibacterial effect of AgNPs exhibited significant results compared to the plant extract and realized that plant synthesized AgNPs have been the best alternative to antibiotics. Finally, the antioxidant activity of AgNPs also shown excellent results as compared to the plant extract.

\section{Funding}

This research received no external funding.

\section{Acknowledgments}

The authors would like to acknowledge the support and facilitate provided by Hazara University Mansehra, Pakistan, and the University of AJK, Pakistan.

\section{Conflicts of Interest}

The authors declare no conflict of interest.

\section{References}

1. Hamouda, R.A.; Hussein, M.H.; Abo-elmagd; R.A. et al. Synthesis and biological characterization of silver nanoparticles derived from the cyanobacterium Oscillatoria limnetica. Scientific Reports 2019, 9, 13071. https://doi.org/10.1038/s41598-019-49444-y

2. Vega-Baudrit, J.; Gamboa, S.M.; Rojas, E.R.; Martinez, V.V. Synthesis and characterization of silver nanoparticles and their application as an antibacterial agent. International Journal of Biosensors \& Bioelectronics 2019, 5.

3. De Marco, B.A.; Rechelo, B.S.; Tótoli, E.G.; Kogawa, A.C.; Salgado, H.R.N. Evolution of green chemistry and its multidimensional impacts: A review. Saudi Pharmaceutical Journal 2019, 27, 1-8.

4. Loste, N.; Chinarro, D.; Gomez, M.; Roldán, E.; Giner, B. Assessing awareness of green chemistry as a tool for advancing sustainability. Journal of Cleaner Production 2020, 256, 120392.

5. Hurst, G.A. Systems thinking approaches for international green chemistry education. Current Opinion in Green and Sustainable Chemistry 2020, 21, 93-97.

6. Falcone, P.M.; Hiete, M. Exploring green and sustainable chemistry in the context of sustainability transition: The role of visions and policy. Current Opinion in Green and Sustainable Chemistry 2019, 19, 66-75.

7. Premanand, G.; Shanmugam, N.; Kannadasan, N.; Sathishkumar, K.; Viruthagiri, G. Nelumbo nucifera leaf extract mediated synthesis of silver nanoparticles and their antimicrobial properties against some human pathogens. Applied Nanoscience 2016, 6, 409-415, https://doi.org/10.1007/s13204-015-0442-6.

8. Sumi Maria, B.; Devadiga, A.; Shetty Kodialbail, V.; Saidutta, M.B. Synthesis of silver nanoparticles using medicinal Zizyphus xylopyrus bark extract. Applied Nanoscience 2015, 5, 755-762, https://doi.org/10.1007/s13204-014-0372-8.

9. Sathishkumar, M.; Sneha, K.; Won, S.W.; Cho, C.W.; Kim, S.; Yun, Y.S. Cinnamon zeylanicum bark extract and powder mediated green synthesis of nanocrystalline silver particles and its bactericidal activity. Colloids and Surfaces B: Biointerfaces 2009, 73, 332-338, https://doi.org/10.1016/j.colsurfb.2009.06.005. 
10. Mohanta, Y.K.; Panda, S.K.; Jayabalan, R.; Sharma, N.; Bastia, A.K.; Mohanta, T.K. Antimicrobial, Antioxidant and Cytotoxic Activity of Silver Nanoparticles Synthesized by Leaf Extract of Erythrina suberosa (Roxb.). Front. Mol. Biosci. 2017, 4, https://doi.org/10.3389/fmolb.2017.00014.

11. Thilagavathi, T.; Kathiravan, G.K.S. Antioxidant activity and synthesis of silver Nanoparticles using the leaf extract of Limonia Acidissima. International Journal of Pharma and Bio Sciences 2016, 7, https://doi.org/10.22376/ijpbs.2016.7.4.b201-205.

12. Prathna, T.C.; Chandrasekaran, N.; Raichur, A.M.; Mukherjee, A. Biomimetic synthesis of silver nanoparticles by Citrus limon (lemon) aqueous extract and theoretical prediction of particle size. Colloids and Surfaces B: Biointerfaces 2011, 82, 152-159, https://doi.org/10.1016/j.colsurfb.2010.08.036.

13. Bar, H.; Bhui, D.K.; Sahoo, G.P.; Sarkar, P.; De, S.P.; Misra, A. Green synthesis of silver nanoparticles using latex of Jatropha curcas. Colloids and Surfaces A: Physicochemical and Engineering Aspects 2009, 339, 134-139, https://doi.org/10.1016/j.colsurfa.2009.02.008.

14. Shah, M.; Poinern, G.E.J.; Fawcett, D. Biogenic synthesis of silver nanoparticles via indigenous Anigozanthos manglesii, (red and green kangaroo paw) leaf extract and its potential antibacterial activity. Int. J. Res. Med. Sci. 2016, 3427-3432, https://doi.org/10.18203/2320-6012.ijrms20162306.

15. Ibrahim, H.M.M. Green synthesis and characterization of silver nanoparticles using banana peel extract and their antimicrobial activity against representative microorganisms. Journal of Radiation Research and Applied Sciences 2015, 8, 265-275, https://doi.org/10.1016/j.jrras.2015.01.007.

16. Ramesh, P.S.; Kokila, T.; Geetha, D. Plant mediated green synthesis and antibacterial activity of silver nanoparticles using Emblica officinalis fruit extract. Spectrochimica Acta Part A: Molecular and Biomolecular Spectroscopy 2015, 142, 339-343, https://doi.org/10.1016/j.saa.2015.01.062.

17. Roy, K.; Sarkar, C.; Ghosh, C. Single-step novel biosynthesis of silver nanoparticles using Cucumis sativus fruit extract and study of its photcatalytic and antibacterial activity. Digest Journal of Nanomaterials and Biostructures 2015, 10, 107-115.

18. Moteriya, P.; Chanda, S. Synthesis and characterization of silver nanoparticles using Caesalpinia pulcherrima flower extract and assessment of their in vitro antimicrobial, antioxidant, cytotoxic, and genotoxic activities. Artificial Cells, Nanomedicine, and Biotechnology 2017, 45, 1556-1567, https://doi.org/10.1080/21691401.2016.1261871.

19. Mitiku, A.; Yilma, B. Antibacterial and antioxidant activity of silver nanoparticles synthesized using aqueous extract of Moringa stenopetala leaves. African Journal of Biotechnology 2017, 16, 1705-1716, https://doi.org/10.5897/AJB2017.16010.

20. Forough, M.; Farhadi, K. Biological and green synthesis of silver nanoparticles. Turkish J. Eng. Env. Sci 2010, 34, 281-287, https://doi.org/10.3906/muh-1005-30.

21. Ajmal, N.; Saraswat, K.; Sharma, V.; Zafar, M.E. Synthesis and Antibacterial activity of Silver nanoparticles from Prunus armeniaca ( Apricot) fruit peel extract. Bull. Environ. Pharmacol. Life Sci. 2016, 5, 91-94.

22. Patra, J.K.; Baek, K.-H. Green synthesis of silver chloride nanoparticles using Prunus persica L. outer peel extract and investigation of antibacterial, anticandidal, antioxidant potential. Green Chemistry Letters and Reviews 2016, 9, 132-142, https://doi.org/10.1080/17518253.2016.1192692.

23. Saravanakumar, A.; Peng, M.M.; Ganesh, M.; Jayaprakash, J.; Mohankumar, M.; Jang, H.T. Low-cost and eco-friendly green synthesis of silver nanoparticles using Prunus japonica (Rosaceae) leaf extract and their antibacterial, antioxidant properties. Artificial Cells, Nanomedicine, and Biotechnology 2017, 45, 11651171, https://doi.org/10.1080/21691401.2016.1203795.

24. Premasudha, P.; Venkataramana, M.; Abirami, M.; Vanathi, P.; Krishna, K.; Rajendran, R. Biological synthesis and characterization of silver nanoparticles using Eclipta alba leaf extract and evaluation of its cytotoxic and antimicrobial potential. Bulletin of Materials Science 2015, 38, 965-973, https://doi.org/10.1007/s12034-015-0945-5.

25. Saminathan, K. Herbal Synthesis of Silver Nanoparticles using Eclipta alba and its antimicrobial activity. Int. J. Curr. Microbiol. Appl. Sci. 2015, 4, 1092-1097.

26. Ahmed, S.; Saifullah; Ahmad, M.; Swami, B.L.; Ikram, S. Green synthesis of silver nanoparticles using Azadirachta indica aqueous leaf extract. Journal of Radiation Research and Applied Sciences 2016, 9, 1-7, https://doi.org/10.1016/j.jrras.2015.06.006.

27. McDonald, S.; Prenzler, P.D.; Antolovich, M.; Robards, K. Phenolic content and antioxidant activity of olive extracts. Food Chemistry 2001, 73, 73-84, https://doi.org/10.1016/S0308-8146(00)00288-0.

28. De Leo, M.E.; Tranghese, A.; Passantino, M.; Mordente, A.; Lizzio, M.M.; Galeotti, T.; Zoli, A. Manganese superoxide dismutase, glutathione peroxidase, and total radical trapping antioxidant capacity in active rheumatoid arthritis. The Journal of rheumatology 2002, 29, 2245-2246.

29. Thirumurugan, A. Biotechnological synthesis of gold nanoparticles of Azadirachta indica leaf extract. International journal of Biological Technology 2010, 75-77.

30. Shankar, S.S.; Rai, A.; Ahmad, A.; Sastry, M. Controlling the Optical Properties of Lemongrass Extract Synthesized Gold Nanotriangles and Potential Application in Infrared-Absorbing Optical Coatings. Chemistry of Materials 2005, 17, 566-572, https://doi.org/10.1021/cm048292g.

31. Shameli, K.; Bin Ahmad, M.; Jaffar Al-Mulla, E.A.; Ibrahim, N.A.; Shabanzadeh, P.; Rustaiyan, A.; Abdollahi, Y.; Bagheri, S.; Abdolmohammadi, S.; Usman, M.S.; Zidan, M. Green Biosynthesis of Silver 
Nanoparticles Using Callicarpa maingayi Stem Bark Extraction. Molecules 2012, 17, 8506-8517, https://doi.org/10.3390/molecules17078506.

32. Elavazhagan, T.; Arunachalam, K.D. Memecylon edule leaf extract mediated green synthesis of silver and gold nanoparticles. Int J Nanomedicine 2011, 6, 1265-1278, https://doi.org/10.2147/IJN.S18347.

33. Sarkar, R.; Kumbhakar, P.; Mitra, A. Green synthesis of silver nanoparticles and its optical properties. Digest Journal of Nanomaterials and Biostructures 2010, 5, 491-496.

34. Basker, G.S. Ecofriendly synthesis of silver nanoparticles from Eichhornia crassipes. Int. J. Curr. Res. Biosci. Plant Biol. 2016, 3, 56-61.

35. Bonigala, B.; Usha, K.; Vijayalakshmi, M.; Sambasiva, R.; Ravi, V.; Poda, S.J.J.P.R. Green synthesis of silver nanoparticles from leaf extract of Cascabela thevetia, physicochemical characterization and antimicrobial activity. J. Pharm. Res. 2016, 10, 410-418.

36. Nagaonkar, D.; Rai, M. Sequentially Reduced Biogenic Silver-Gold Nanoparticles With Enhanced Antimicrobial Potential Over Silver And Gold Monometallic Nanoparticles. Advanced Material Letters 2015, 6, 334-341, https://doi.org/10.5185/amlett.2015.5737.

37. Banerjee, P.; Satapathy, M.; Mukhopahayay, A.; Das, P. Leaf extract mediated green synthesis of silver nanoparticles from widely available Indian plants: synthesis, characterization, antimicrobial property and toxicity analysis. Bioresources and Bioprocessing 2014, 1, https://doi.org/10.1186/s40643-014-0003-y.

38. Mohan, Y.M.; Raju, K.M.; Sambasivudu, K.; Singh, S.; Sreedhar, B. Preparation of acacia-stabilized silver nanoparticles: A green approach. Journal of Applied Polymer Science 2007, 106, 3375-3381, https://doi.org/10.1002/app.26979.

39. Padalia, H.; Moteriya, P.; Chanda, S. Green synthesis of silver nanoparticles from marigold flower and its synergistic antimicrobial potential. Arabian Journal of Chemistry 2015, 8, 732-741, https://doi.org/10.1016/j.arabjc.2014.11.015.

40. Pourmortazavi, S.M.; Taghdiri, M.; Makari, V.; Rahimi-Nasrabadi, M. Procedure optimization for green synthesis of silver nanoparticles by aqueous extract of Eucalyptus oleosa. Spectrochimica Acta Part A: Molecular and Biomolecular Spectroscopy $\quad \mathbf{2 0 1 5}, \quad 136, \quad 1249-1254$, https://doi.org/10.1016/j.saa.2014.10.010.

41. Krithiga, N.; Rajalakshmi, A.; Jayachitra, A. Green Synthesis of Silver Nanoparticles Using Leaf Extracts of Clitoria ternatea and Solanum nigrum and Study of Its Antibacterial Effect against Common Nosocomial Pathogens. J. Nanosci. 2015, 2015, https://doi.org/10.1155/2015/928204.

42. Parlinska-Wojtan, M.; Kus-Liskiewicz, M.; Depciuch, J.; Sadik, O. Green synthesis and antibacterial effects of aqueous colloidal solutions of silver nanoparticles using camomile terpenoids as a combined reducing and capping agent. Bioprocess and Biosystems Engineering 2016, 39, 1213-1223, https://doi.org/10.1007/s00449-016-1599-4.

43. Ganapathy Selvam, G.; Sivakumar, K. Phycosynthesis of silver nanoparticles and photocatalytic degradation of methyl orange dye using silver (Ag) nanoparticles synthesized from Hypnea musciformis (Wulfen) J.V. Lamouroux. Applied Nanoscience 2015, 5, 617-622, https://doi.org/10.1007/s13204-014-0356-8.

44. Awwad, A.; Salem, N. Green Synthesis of Silver Nanoparticles byMulberry LeavesExtract. Journal of Nanoscience and Nanotechnology 2012, 2, 125-128, https://doi.org/10.5923/j.nn.20120204.06.

45. Shekhawat, M.; Kannan, N.; Manokari, M. Biogenesis of silver nanoparticles using leaf extract of Turnera ulmifolia Linn. and screening of their antimicrobial activity. J. Ecobiotechnology 2012, 4, 54-57, https://doi.org/10.13140/RG.2.2.11703.55202.

46. Chen, S.F.; Li, J.P.; Qian, K.; Xu, W.P.; Lu, Y.; Huang, W.X.; Yu, S.H. Large scale photochemical synthesis of $\mathrm{M} @ \mathrm{TiO} 2$ nanocomposites $(\mathrm{M}=\mathrm{Ag}, \mathrm{Pd}, \mathrm{Au}, \mathrm{Pt})$ and their optical properties, $\mathrm{CO}$ oxidation performance, and antibacterial effect. Nano Research 2010, 3, 244-255, https://doi.org/10.1007/s12274-010-1027-z.

47. Chudasama, B.; Vala, A.K.; Andhariya, N.; Upadhyay, R.V.; Mehta, R.V. Enhanced antibacterial activity of bifunctional Fe3O4-Ag core-shell nanostructures. Nano Research 2009, 2, 955-965, https://doi.org/10.1007/s12274-009-9098-4.

48. Kvítek, L.; Panáček, A.; Soukupová, J.; Kolář, M.; Večeřová, R.; Prucek, R.; Holecová, M.; Zbořil, R. Effect of Surfactants and Polymers on Stability and Antibacterial Activity of Silver Nanoparticles (NPs). The Journal of Physical Chemistry C 2008, 112, 5825-5834, https://doi.org/10.1021/jp711616v.

49. Lee, D.; Cohen, R.E.; Rubner, M.F. Antibacterial Properties of Ag Nanoparticle Loaded Multilayers and Formation of Magnetically Directed Antibacterial Microparticles. Langmuir 2005, 21, 9651-9659, https://doi.org/10.1021/la0513306.

50. Sulaiman, G.M.; Mohammed, W.H.; Marzoog, T.R.; Al-Amiery, A.A.A.; Kadhum, A.A.H.; Mohamad, A.B. Green synthesis, antimicrobial and cytotoxic effects of silver nanoparticles using Eucalyptus chapmaniana leaves extract. Asian Pacific Journal of Tropical Biomedicine 2013, 3, 58-63, https://doi.org/10.1016/S2221-1691(13)60024-6.

51. Gilani, A.H.; Aziz, N.; Ali, S.M.; Saeed, M. Pharmacological basis for the use of peach leaves in constipation. Journal of Ethnopharmacology 2000, 73, 87-93, https://doi.org/10.1016/S03788741(00)00288-9. 
52. Prior, R.L.; Wu, X.; Schaich, K. Standardized Methods for the Determination of Antioxidant Capacity and Phenolics in Foods and Dietary Supplements. J Agric Food Chem 2005, 53, 4290-4302, https://doi.org/10.1021/jf0502698.

53. Swamy, M.K.; Akhtar, M.S.; Mohanty, S.K.; Sinniah, U.R. Synthesis and characterization of silver nanoparticles using fruit extract of Momordica cymbalaria and assessment of their in vitro antimicrobial, antioxidant and cytotoxicity activities. Spectrochimica Acta Part A: Molecular and Biomolecular Spectroscopy 2015, 151, 939-944, https://doi.org/10.1016/j.saa.2015.07.009. 